Lubomir Kmeco,

D. Sc., University College of Business in Prague, Czech Republic

Jiri Mezulanik,

D. Sc., University of Entrepreneurship and Law, Czech Republic

Alena Kascakova,

Ph.D., Matej Bel University in Banska Bystrica, Slovak Republic

Mehmet Civelek,

Ph.D., University of Entrepreneurship and Law, Czech Republic

\title{
FACTORS OF DEMAND FOR CULTURAL EVENTS IN TOURISM: THE CASE OF THE CZECH REPUBLIC
}

\begin{abstract}
The main purpose of the research is to examine selected demand factors for cultural events in tourism in the Czech Republic. Eight hypotheses are formulated. The primary research was carried out in the form of a questionnaire. There were 1666 respondents interviewed in various tourist destinations in the Czech Republic. While testing the hypotheses the Friedman test, Wilcoxon signed-rank test, the Mann-Whitney U test, and Spearman's rank correlation coefficient are used. We confirm the hypotheses that the residents of the Czech Republic think that cultural events are organized more frequently than sports events, shopping events (e.g. markets, trades), exhibitions and fairs, and religious events in the Czech Republic, the motives for participation in cultural events are mainly experience and entertainment, women more often participate in cultural events than men, men more often attend sports events than women, and people take the greatest pleasure to participate in cultural events and not in the other events (sports events, shopping events, exhibitions and fairs, and religious events). We reject the hypotheses that summer is the best season for organizing events, that families are more likely to participate in cultural events than single people or people with friends, and that advertising in mass media has the greatest influence on the decision to visit cultural events. The benefit of the paper is to focus the research on a new area of tourism development in the Czech Republic - organizing events at tourist destinations and trying to reveal the impact of various factors on demand for cultural events. Organization of events in tourism is a relatively large area, therefore, it opens further possibilities of exploring this issue in terms of the organized events' impact on tourist destinations, the offering of organized events, managing organized events.
\end{abstract}

Keywords: cultural events, exhibitions, fairs, Friedman test, Mann-Whitney U test, Spearman's rank correlation coefficient, shopping events, sports events, Wilcoxon signed-rank test.

Introduction. The current tourism market is characterized by a strong competitive environment that changes the customers and their attitudes and requirements on one side (Çelik, 2019) and requires continuous product innovation and creation of new segments of tourist products on the other (Kljucnikov et al., 2018; Krajcik et al., 2019). There is also strong competition between the destinations themselves. It is therefore essential for tourist destinations to exploit new opportunities for revitalizing and supporting the development of tourism, such as various interesting and attractive products. Such tourism products can also include organized events that can be used by destinations to attract visitors, develop tourism, revitalize various activities and places (Hernandez-Mogollon et al., 2018). In the world, unlike the Czech Republic, more attention is paid to organized events, as event tourism is a rapidly developing part of tourism that allows countries to profit from growth in income and employment in tourism, to build their competitive advantages (Boucher et al., 2018; Christou et al., 2018; Baez-Montenegro \& DevesaFernandez, 2017), create destination image and attract foreign investment and visitor attention (BaezMontenegro \& Devesa-Fernandez, 2017; Duran \& Hamarat, 2014). In addition to image creation, event tourism reduces crime and poverty and makes people prouder of their country (Boucher et al., 2018). As a result of event tourism, marketing activities aimed at promoting destinations are also improving (Hernandez-Mogollon et al., 2018; Duran \& Hamarat, 2014). Event tourism, like other tourism activities,

Cite as: Kmeco, L., Mezulanik, J., Kascakova, A. \& Civelek, M. (2019). Factors of Demand for Cultural Events in Tourism: the Case of the Czech Republic. Marketing and Management of Innovations, 4, 118-128. http://doi.org/10.21272/mmi.2019.4-10 
evokes various socio-cultural (Duran \& Hamarat, 2014), economic (Yolal et al., 2012; Duran \& Hamarat, 2014; Valek, 2018) and environmental effects on destinations (Boucher et al., 2018).

The Czech Republic is one of the countries that have a significant cultural heritage. Cultural heritage is well placed to become a part of tourism products such as cultural events. We have therefore focused our research on the field of cultural events and factors that influence participation in events of this kind. The structure of this research article is the following. In the theoretical part, we present the opinions of the leading experts of the researched area. The next part describes the scientific methods and data we work within the article and at the same time, we formulate scientific hypotheses. Subsequently, we present and interpret the results of our empirical research. In the discussion section, we compare the results of our research with similar scientific studies conducted abroad. The originality of our research lies in the fact that we present the results of scientific research in a field that is not systematically researched in the Czech Republic.

Literature Review. The importance of event tourism for the development of destination cities is also evidenced by the fact that in 2005 the European Commission published a study «The impact of major cultural and sports events on tourism-oriented SMEs», it aims to assess social, economic and environmental impact of major cultural and sports events on destinations and local tourism businesses. The study provided information on the potential of such events and the need for cooperation at the regional level to organize events on sustainable development principles for policymakers, small and medium-sized enterprises and local communities (Groupe AMNYOS Consultants for DG Enterprise and Industry, 2005). In the latest survey of holiday motives of EU citizens in 2016, 9\% of EU citizens identified the motive for the participation in organized events as the main motive of their holiday in 2015. The results of this research shown in Table 1.

Table 1. The main motives to take a vacation in 2015

\begin{tabular}{|c|c|c|}
\hline The motive to take a vacation/Population in the EU and the Czech Republic (CZ) in \% & EU & CZ \\
\hline Sunshine and beach & 39 & 31 \\
\hline Visit family and friends & 38 & 32 \\
\hline Nature (mountains, lake, landscape, etc.) & 31 & 55 \\
\hline City trips & 27 & 19 \\
\hline Culture (religion, gastronomy, art, etc.) & 26 & 24 \\
\hline Wellness, spa, resp. health care & 13 & 19 \\
\hline Sports activities (diving, cycling, etc.) & 12 & 24 \\
\hline Specific events (sports events, festivals, parties, etc.) & 9 & 9 \\
\hline Another motive & 13 & 12 \\
\hline Did not answer & 1 & 1 \\
\hline
\end{tabular}

Source: Directorate-General (2016).

In addition to traditional holiday motives, such as sunshine and beach, visiting relatives and friends, nature, culture, EU citizens quite often travelled outside their usual residence to visit interesting organized events. Therefore, in recent years, more and more tourist destinations use organized events as a tool for tourism dynamics and through their varied offer, especially in summer, try to attract the visitors' attention (Pompurova, 2014).

Cultural events are an important part of event tourism and can suitably complement the product range of small businesses in rural tourism and agritourism (Mura \& Kljucnikov, 2018). Cultural events currently account for $1 / 5$ of the total tourism market in the world; organizing these events brings various social, economic and environmental benefits for countries and their citizens (Boucher et al., 2018). Cultural events include various activities related to visiting festivals, local celebrations, architecture, rituals and other interesting events at the destination places (Hernandez-Mogollon et al., 2018; Christou et al., 2018); they 
may consist of rituals, performances, ceremonies, festivals and celebrations to present socio-cultural habits (Oklobdzija, 2015). The atmosphere and uniqueness of cultural events arise from the places where events are organized. These factors can be used as appropriate marketing tools to differentiate the destination from other places and build its image (Hernandez-Mogollon et al., 2018). As tourism destinations and culture are strongly interrelated, tourism policymakers and other stakeholders in tourism development can use the destination to attract visitors and make them visit their destination (Christou et al., 2018; Hernandez-Mogollon et al. 2018).

Also, the interconnection of the destination and the culture can improve its identity and intensify the development of cultural tourism based on the cultural values and traditions of the destination. Besides, during cultural events such as Easter or wine festivals, there is an increase in the capacity use of accommodation facilities, which is reflected in the increase in accommodation prices and income growth in local economies. Cultural events turn visitors into more cultural and educated people and improve them from a psychological point of view (Hernandez-Mogollon et al., 2018). Cultural events are considered tourist attractions (Christou et al., 2018). The number of different cultural events and festivals has increased significantly in recent years (Baez-Montenegro \& Devesa-Fernandez, 2017). Cultural events and various festivals have thus become an important factor in the development of tourism BaezMontenegro \& Devesa-Fernandez, 2017; Christou et al., 2018).

Methodology and research methods. This article aims to broaden and deepen scientific knowledge in the field of organized tourism events, focusing on selected factors of demand for cultural events in tourism. Selected factors of demand for cultural events in the Czech Republic are examined. The object of the research are factors of demand for cultural events in tourism in the Czech Republic. The primary research was conducted in the form of a questionnaire survey. The questionnaire survey was carried out by trained interviewers at various tourist destinations in the Czech Republic in 2017/2018. The basic set - the population in the Czech Republic older than 15 years, consisted of 8,930,864 inhabitants of the Czech Republic, of which $48.79 \%$ were men and $51.21 \%$ were women (mid-year population by the 1 July 2017). In determining the sample size, we used the confidence level of $95 \%$ and a sampling error of $2 \%$, which is the minimum value considered in marketing surveys (its level is $2-10 \%$ ) and defines the accuracy of the estimate. After collecting the questionnaires, we have excluded from processing those that were not filled in correctly or were incomplete. After omitting these questionnaires, the size of the research sample was 1666 , while the permissible estimation error increased only slightly, to $2.4 \%$. The selected set was representative in terms of gender, we verified the representativeness of the sample by the $x^{2}$ test (Chisquare Test), where the $p$-value $=0.337$. The questionnaire consisted of 22 questions. In merit questions we asked about the frequency of visits events, their attractiveness, promotion, the influence of seasonality on the organization of events, we found motives of attendance, most often kinds of organized events, satisfaction with participation in events and so on. At the end of the questionnaire, we asked questions to determine the demographic characteristics of respondents (e.g. gender, age).

We used the statistical analysis tool SPSS (version 25) to analyse the data obtained by the questionnaire survey. To test the hypotheses below, we used a $5 \%$ significance level and used various assays, such as the Friedman test and the Wilcoxon signed-rank test (hypotheses H1, H2, H3, H8), Spearman's rank correlation coefficient (hypotheses H4, H5, H6) and the Mann - Whitney U test (hypothesis $\mathrm{H7}$ ). The appropriate statistical test was chosen based on the assessment of several criteria - depending on the variable(s), the number of files to be compared and whether we want to compare the research files or look for relationships (correlations):

Hypothesis H1: The residents of the Czech Republic think that cultural events are organized more frequently than sports events, shopping events (e.g. markets, trades), exhibitions and fairs, and religious events.

Hypothesis H2: In the opinion of the inhabitants of the Czech Republic, the summer season is the 
L. Kmeco, J. Mezulanik, A. Kascakova \& M. Civelek. Factors of Demand for Cultural Events in Tourism: the Case of the Czech Republic

most suitable for organizing events at the tourist destinations.

Hypothesis H3: The most important motives for visiting cultural events are experience and entertainment.

Hypothesis H4: Women are more often visit cultural events than men.

Hypothesis H5: Men are more often participate in sports events than women.

Hypothesis H6: Families are more often participate in cultural events that singles or friends.

Hypothesis H7: Among all kinds of organized events people take the greatest pleasure to participate in cultural events.

Hypothesis H8: Advertising in the mass media plays a major role in the decision to visit cultural events.

Results. The results of the research are presented in the following tables. Table 2 and Table 3 show the results of testing the first hypothesis.

Table 2. Frequency of individual types of events

\begin{tabular}{|c|c|}
\hline \multicolumn{2}{|c|}{ Friedman test } \\
\hline $\mathrm{N}$ & 1662 \\
\hline Chi-squared test & 1935,834 \\
\hline $\mathrm{Df}$ & 5 \\
\hline Asymp. Sig. & 0,000 \\
\hline
\end{tabular}

Source: own data processing.

The Friedman test showed that there is a statistically significant difference between the frequency of organizing individual types of events ( $p$-value $=0,000)$.

Table 3. The sequence of the frequency of individual types of events

\begin{tabular}{|c|c|}
\hline \multicolumn{2}{|c|}{ Wilcoxon signed-rank test } \\
\hline Types of events & Asymp. Sig (2-tailed) \\
\hline Sports events/Cultural events & 0,000 \\
\hline Shopping events/Sports events & 0,632 \\
\hline Exhibitions and trade fairs/Shopping events & 0,000 \\
\hline Other events/ Exhibitions and trade fairs & 0,000 \\
\hline Religious events/Other events & 0,386 \\
\hline
\end{tabular}

Source: own data processing.

Wilcoxon signed-rank test revealed that, according to the Czech Republic population, cultural events $(p$-value $=0)$ are organized more frequently in their country than other types of events; cultural events are followed by sports and shopping events together ( $p$-value $=0.632)$, exhibitions and fairs ( $p$-value $=0$ ), religious and other events together ( $p$-value $=0.386$ ). The hypothesis was confirmed. The results of testing the second hypothesis shown in Table 4 and Table 5.

Table 4. The best time of year for organizing events

\begin{tabular}{|c|c|}
\hline \multicolumn{2}{|c|}{ Friedman test } \\
\hline $\mathrm{N}$ & 1657 \\
\hline Chi-squared test & 695,533 \\
\hline Df & 3 \\
\hline Asymp. Sig. & 0,000 \\
\hline
\end{tabular}

Source: own data processing.

The Friedman test revealed that there are differences between the answers to our question, which 
L. Kmeco, J. Mezulanik, A. Kascakova \& M. Civelek. Factors of Demand for Cultural Events in Tourism: the Case of the Czech Republic

part of the year is most suitable for organizing events $(p$-value $=0.000)$.

Table 5. The best time of year for organizing events

\begin{tabular}{|c|c|}
\hline \multicolumn{2}{|c|}{ Wilcoxon signed-rank test } \\
\hline Time of year & Asymp. Sig (2-tailed) \\
\hline Summer season/Doesn't matter what season & 0,001 \\
\hline Off-season/Summer season & 0,000 \\
\hline Winter season/ Offseason & 0,148 \\
\hline
\end{tabular}

Source: own data processing.

According to the Wilcoxon signed-rank test, respondents most often answered that it doesn't matter what season the event is organized ( $p$-value $=0,001$ ), they were followed by a group of respondents who consider summer as the most suitable season for organizing events ( $p$-value $=0)$ and then in last place respondents considered the winter and off-season together as the least suitable times of the year for organizing events ( $p$-value $=0,148$ ). The hypothesis was rejected. The results of testing the third hypothesis shown in Table 6 and Table 7.

Table 6. Motives for visiting cultural events

\begin{tabular}{|c|c|}
\hline \multicolumn{2}{|c|}{ Friedman test } \\
\hline $\mathrm{N}$ & 888 \\
\hline Chi-squared test & 1671,344 \\
\hline $\mathrm{Df}$ & 8 \\
\hline Asymp. Sig. & 0,000 \\
\hline
\end{tabular}

Source: own data processing.

The Friedman test confirmed that there were statistically significant differences in motives of attending cultural events ( $p$-value $=0)$.

Table 7. The sequence of motives for visiting cultural events

\begin{tabular}{|c|c|}
\hline \multicolumn{2}{|c|}{ Wilcoxon signed-rank test } \\
\hline Motives for visiting events & Asymp. Sig (2-tailed) \\
\hline Fun/Experience & 0,274 \\
\hline Relaxation/Fun & 0,000 \\
\hline Distraction/Relaxation & 0,042 \\
\hline Obtaining new information/Distraction & 0,000 \\
\hline Learning/ Obtaining new information & 0,000 \\
\hline Shopping/Learning & 0,027 \\
\hline Spiritual enrichment/Shopping & 0,001 \\
\hline Other motives/Spiritual enrichment & 0,000 \\
\hline
\end{tabular}

Source: own data processing.

We used the Wilcoxon test to determine the order of motives of attending cultural events. We found that the most common motives to visit cultural events are experience and fun together ( $p$-value $=0,274$ ), following is relaxation ( $p$-value $=0)$, distraction ( $p$-value $=0,042)$, obtaining new information ( $p$-value $=0$ ), learning ( $p$-value $=0)$, shopping ( $p$-value $=0,027)$, spiritual enrichment $(p$-value $=0,001)$ and other motive $(p$-value $=0)$. The hypothesis was confirmed. The results of testing the fourth hypothesis shown in Table 8 . 
L. Kmeco, J. Mezulanik, A. Kascakova \& M. Civelek. Factors of Demand for Cultural Events in Tourism: the Case of the Czech Republic

Table 8. Participation of women in cultural events (Spearman's coefficient)

\begin{tabular}{|c|c|}
\hline & Gender \\
\hline Cultural events & 0,138 \\
\hline Sig. (2-tailed) & 0,000 \\
\hline N & 1538 \\
\hline
\end{tabular}

Source: own data processing.

The hypothesis was confirmed $(p$-value $=0)$, but it is a weak dependence (correlation coefficient $=$ 0.138). The results of testing the sixth hypothesis shown in Table 9.

Table 9. Participation of men in sports events (Spearman's coefficient)

\begin{tabular}{|c|c|}
\hline & Gender \\
\hline Sports events & $-0,220$ \\
\hline Sig. (2-tailed) & 0,000 \\
\hline N & 1539 \\
\hline
\end{tabular}

Source: own data processing.

The hypothesis was confirmed ( $p$-value $=0$ ), but dependency is weak in this case too (correlation coefficient $=-0.220$ ). The results of testing the seventh hypothesis shown in Table 10 .

Table 10. Family participation in cultural events (Spearman's coefficient)

\begin{tabular}{|c|c|}
\hline & Families \\
\hline Cultural events & 0,048 \\
\hline Sig. (2-tailed) & 0,061 \\
\hline $\mathrm{N}$ & 1521 \\
\hline
\end{tabular}

Source: own data processing.

The hypothesis was rejected $(p-v a l u e=0.061)$. The results of the verification of the seventh hypothesis presented in Table 11.

Table 11. Satisfaction with cultural events (Mann - Whitney test)

\begin{tabular}{|c|c|}
\hline & Satisfaction with cultural events \\
\hline Mann-Whitney U & 218478,000 \\
\hline Wilcoxon W & 376119,000 \\
\hline Z & $-2,197$ \\
\hline Asymp. Sig. (2-tailed) & 0,028 \\
\hline
\end{tabular}

Source: own data processing.

The hypothesis was confirmed ( $p$-value $=0.028)$. The results of testing the eighth hypothesis shown in Table 12 and Table 13.

Table 12. Impact of various sources influencing attendance of events

\begin{tabular}{|c|c|}
\hline \multicolumn{2}{|c|}{ Friedman test } \\
\hline $\mathrm{N}$ & 664 \\
\hline Chi-Square & 488,223 \\
\hline Df & 5 \\
\hline Asymp. Sig. & 0,000 \\
\hline
\end{tabular}

Source: own data processing. 
L. Kmeco, J. Mezulanik, A. Kascakova \& M. Civelek. Factors of Demand for Cultural Events in Tourism: the Case of the Czech Republic

The Friedman test revealed that the sources of information we asked did not affect people equally ( $p$ value $=0$ ).

Table 13. The sequence of various sources influencing attendance of events

\begin{tabular}{|c|c|}
\hline \multicolumn{2}{|c|}{ Wilcoxon signed-rank test } \\
\hline Sources influencing attendance of events & Asymp. Sig (2-tailed) \\
\hline Relatives and acquaintances recommendation/Own experience & 0,023 \\
\hline Mass media advertising/ Relatives and acquaintances recommendation & 0,000 \\
\hline Coincidence/ Mass media advertising & 0,005 \\
\hline Another source/Coincidence & 0,000 \\
\hline Travel agency offer/Another source & 0,063 \\
\hline
\end{tabular}

Source: own data processing.

Using of Wilcoxon test to determine the order of the sources of information that visitors used when deciding to participate in the event. We have found that the most frequently used information source is our own experience ( $p$-value $=0,023$ ), following is relatives and acquaintances recommendation ( $p$-value $=$ 0 ), mass media advertising ( $p$-value $=0.005)$, coincidence $(p$-value $=0)$, another source and travel agency offer together ( $p$-value $=0.063)$. The last hypothesis was rejected.

Conclusions. Based on our results, we conclude that according to the population of the Czech Republic cultural events are organized in their country more frequently than other events (sports, shopping, exhibitions and fairs, religious and other events). This fact indirectly corresponds with knowledge from abroad, e.g. Boucher et al. (2018) claim that cultural events and festivals represent around $20 \%$ of the total tourism market, according to Baez-Montenegro \& Devesa-Fernandez (2017), the number of different cultural events and festivals has increased significantly in recent years. This fact demonstrates the importance of cultural events in the development of tourism in tourist destinations in the Czech Republic and should not escape the attention of tourism policymakers at all levels and managers of tourism development in destinations that have a significant cultural heritage. Through the organization of cultural events, they can use and enhance the cultural heritage of tourist destinations.

Our finding that year season does not matter for organizing events in the Czech Republic. We thought that summer would be the main season when events are organized at the tourist destinations. We see a contradiction between what we found in the Czech Republic and the findings of foreign authors. When examining seasonality, some authors (Muniz et al., 2014) emphasize that people attend sports and cultural events more often in summer than at other times of the year. Also, Chengcai et al. (2012) highlight the importance of summer for participation in tourism and characterize winter as a less suitable season for tourism development. Pompurova (2014) has a similar opinion according to which summer is the most suitable for organizing events. Conversely, Mendez-Lazaro et al. (2014) examining seasonality as a factor in deciding to participate in tourism in Puerto Rico found that winter is the most suitable season for travelling. It should be noted, that Puerto Rico lies in a different climate zone than the Czech Republic. Our finding that seasons do not affect organizing events may be related to the fact that, according to respondents, that in the Czech Republic cultural events are organized more often and many of them are organized in enclosed spaces (theatres, cinemas, concert halls, etc.), and it is obvious that seasons do not affect the organization of events. Besides, no drama, opera, operetta or musical performances are organized in theatres during the summer season, as theatres have a summer break. Our findings may also be related to the fact that the Czech Republic's inhabitants during the holiday season mostly spend their time in nature (mountains, lakes, etc.) and therefore are not interested in organized events during the summer season.

While examining motivation to participate in cultural events, we found that the most important motives for visiting cultural events are experience and entertainment. This corresponds to the results of foreign 
authors. According to them, among the most frequent motivational factors of participation in all events are not only cultural factors but also new experiences and entertainment (Baez-Montenegro \& DevesaFernandez, 2017; Peter \& Anandkumar, 2015). Regarding the most frequent motivational factors of participation in events, some researchers mention e.g. desire and search for new things, experiences, escape from everyday reality, family cohesion, socialization, curiosity, fun, learning, or the attractiveness of events itself (Baez-Montenegro \& Devesa-Fernandez, 2017; Park et al., 2008; Lee, 2000; Peter \& Anandkumar, 2015). Other scientific studies have also mentioned other factors, such as education (Duran \& Hamarat, 2014, Yolal et al., 2012), relaxation, improving relationships (Duran \& Hamarat, 2014; Peter \& Anandkumar, 2015). Knowing the motives of attendance is of great importance especially for the management of organized events. Tourist destination managers should use our findings to organize not only cultural events in destinations in the Czech Republic but organize them in such a way as to bring events visitors new experience and entertainment, distraction, information, lessons, etc.

The results of our research and the research of foreign authors of gender impact on the choice of participation in an organized event are controversial. Some scientific studies from abroad are confirmed by our findings and others are rejected. We found that women are more often participate in cultural events than men and men are more often participate in sports events than women. This view is also expressed by Yolal et al. (2012) and Peterson et al. (2000), who found that women and more often participate in cultural events, resp. Montgomery \& Robinson (2010), according to which men are more often participate in sports and women - in cultural events (Malchrowicz-Mosko \& Poczta, 2018). However, there is no unambiguous opinion as to whether visitors' gender has an impact on participation in events in foreign literature. Some authors argue that gender impact on participation in events does not exist (Tkaczynski, 2014; Hernandez-Mogollon et al., 2018), according to others, gender affects the selection and attendance of events (Castiglione, 2011; Muniz et al., 2014; Lesic et al., 2017; Montgomery, \& Robinson, 2010). Our finding that women attend more cultural events and men - sports events can be used by tourist destinations management to target groups of people of different genders, offering women participation in cultural events and men - in sports events at the same time in different places of the tourist destination. However, this kind of organized events is only suitable for larger destinations, as it is demanding on finance, human resources, marketing, the actual organization of the event etc.

Among the demographic characteristics that may affect the attendance of cultural events, we also looked at a marital status. We found that families do not more often attend cultural events than single people or people with friends. Similar findings have Peterson et al. (2000), Lewis \& Seaman (2004), who have also found that there is no relationship between marriage (e.g. families) and participation in cultural events. However, even in this area, the results are not unambiguous, because Montgomery \& Robinson (2010), for example, found out by their research that married attend cultural events more than singles.

While examining visitors' satisfaction with cultural events, we found that the greatest pleasure of visiting all kinds of organized events is obtained from cultural events. Similar findings were reached by Christou et al. (2018). Our findings are of great importance in relationship-building between cultural event organizers and their visitors. The fact that events visitors are most satisfied with cultural events is both gratifying and obliging, as it demands continually improving the quality of cultural events. It is challenging for those who decide to organize cultural events.

The last area we investigated was the impact of mass media advertising on the attendance of cultural events. We found that own experience was of the utmost importance to decide whether or not to visit a cultural event, this is followed by recommendations from relatives and acquaintances, and in third place advertising in the mass media. In foreign literature, however, advertising in the mass media is of great importance (Valek, 2018; Yoon et al., 2010; Christou et al., 2018). This finding may also be related to the fact that visitors to cultural events in the Czech Republic are very satisfied with this type of event, know the offer and their own positive experience is enough for them to decide whether to attend the cultural 
event again. In our view, if destination managers want to attract more visitors to cultural events, they should use marketing tools to build public relations, as it has the effect of maintaining and deepening relationships with the visitor (own experience) as well as recommendations from relatives and acquaintances. At the same time, they should intensify their advertising campaign in mass media.

The benefit of our work lies in the fact that we focused our research on a new area of tourism development in the Czech Republic - organizing events at tourist destinations and trying to reveal the impact of various factors on demand for cultural events. Most of our findings also correspond to foreign knowledge. Organization of events in tourism is a relatively large area, therefore, it opens further possibilities of exploring this topic in terms of the organized events' impact on tourist destinations, the offering of organized events, managing organized events and so on. These are the areas in which we plan to target our further research in the future.

Author Contributions: Conceptualization, L. K.; data curation, L.K.; formal analysis, A. K.; investigation, L. K., J. M.; methodology, A. K.; project administration, L. K.; resources. M. C.; J. M.; supervision, L. K.; validation, L. K., J. M. and A. K.; writing-original draft, L. K., M. C.; writing-review \& editing, L. K., J. M. and A. K.

\section{References}

Andersson, T. D., Armbrecht, J. \& Lundberg, E. (2015). Linking Event Quality To Economic Impact: A Study Of Quality, Satisfaction, Use Value And Expenditure At A Music Festival. Journal of Vacation Marketing, 1-19 DOI: 10.1177/1356766715615913 Baez-Montenegro, A. \& Devesa-Fernandez, M. (2017). Motivation, Satisfaction and Loyalty in The Case Of A Film Festival: Differences Between Local And Non-Local Participants. J Cult Econ, 41, 173-195. DOI: 10.1007/s10824-017-9292-2

Boucher, S., Cullen, M. \& Calitz, A. (2018). Factors Influencing Cultural Event Tourism in Nelson Mandela Bay, South Africa. Journal of Tourism and Cultural Change, DOI: 10.1080/14766825.2017.1420070

Castiglione, C., (2011). The Demand For Theatre: A Microeconomic Approach To The Italian Case. Trinity Economics Papers tep0911.Trinity College Dublin, Department of Economics.

Çelik, S. (2019). Does Tourism Change Tourist Attitudes (Prejudice and Stereotype) towards Local People? Journal of Tourism and Services, 10(18): 35-46. https://doi.org/10.29036/jots.v10i18.89

Chengcai, T., Linsheng, Z., McDonald, K. \& Shengkui, C. (2012). A Comprehensive Evaluation of Tourism Climate Suitability in Qinghai Province, China. J. Mt. Sci., 9, 403-413. DOl: 10.1007/s11629-009-2161-5

Christou, P., Sharpley, R. A. \& Farmaki, A. (2018). Exploring The Emotional Dimension Of Visitors' Satisfaction At Cultural Events. Event Management, 22 (2). 255-269. http://dx.doi.org/10.3727/152599518X15173355843389

Dash, P. C. \& Samantaray, M. N. (2018). Exploring Determinants Of A Successful Tourism Experience - The Nabakalebara Event. International Journal of Event and Festival Management, 9(1), 104-119. DOI 10.1108/IJEFM-06-2017-0039

Directorate-General for Enterprise and Industry (2016). Bleskový barometr 432 Preference Evropanů v oblasti cestovniho ruchu. Brusseles: European Union, 2016. Retrieved June 29, 2019, from http://ec.europa.eu/COMMFrontOffice/publicopinion/ index.cfm/Survey/getSurveyDetail/instruments/FLASH/surveyKy/2065

Duran, E. \& Hamarat, B. (2014). Festival Attendees' Motivations: The Case Of International Troia Festival. International Journal of Event and Festival Management, 5 (2), 146-163. DOI 10.1108/IJEFM-07-2012-0020

Groupe AMNYOS Consultants for DG Enterprise and Industry (2005). The impact of major cultural and sporting events on Tourism-oriented SMEs. Retrieved June 29, 2019, from http://ec.europa.eu/growth/content/impact-major-cultural-and-sportingevents-tourism-oriented-smes-0_en

Hernandez-Mogollon, H. M., Duarte, P. A., \& Folgado-Fernandez, J. A. (2018). The Contribution Of Cultural Events To The Formation Of The Cognitive And Affective Images Of A Tourist Destination. Journal of Destination Marketing \& Management, 8, 170-178.

Juandi, V. S., Andari, R. \& Setiyorini, H. P. D. (2017). The Influence of Sustainable Tourism Development towards Tourists' Satisfaction in Saung Angklung Udjo. 1st UPI International Geography Seminar 2017, IOP Publishing IOP Conf. Series: Earth and Environmental Science, 145. DOI:10.1088/1755-1315/145/1/012020

Kljucnikov, A., Krajcik, V., Vincurova, Z. (2018). International Sharing Economy: the Case of Airbnb in the Czech Republic. Economics and Sociology, 11(2), 126-137. doi:10.14254/2071-789X.2018/11-2/9

Kozma, G., Bujdoso, Z., \& Radics, Z. (2014). The Characteristic Feature Of Training Camps In A Lesser-Known Region: A Central European Case Study. Geojournal of Tourism and Geosites, 14(2), 150-157. 
Krajcik, V., Kljucnikov, A., \& Rihova, E. (2019). Innovative Sharing Economy's Business Models in Tourism: Case of Airbnb in Prague. Marketing and Management of Innovations, 2, 108-117. http://doi.org/10.21272/mmi.2019.2-10

Lesic, K. T., Brscic, K., \& Ruzic, M. D. (2017). The Importance Of Understanding Event Experience. Tourism in Southern and Eastern Europe, 4, 605-618.

Lewis, G. B., \& Seaman, B. A. (2004). Sexual Orientation and Demand for the Arts. Social Science Quarterly, 85(3), 523-38.

Lin, T. P., \& Matzarakis, A. (2011). Tourism climate information based on human thermal perception in Taiwan and Eastern China. Tourism Management, 32, 492-500. DOI: 10.1016/ j.tourman.2010.03.017

Malchrowicz-Mosko, E. \& Poczta, J. (2018). A Small-Scale Event and a Big Impact-Is This Relationship Possible in the world of Sport? The Meaning of Heritage Sporting Events for Sustainable Development of Tourism-Experiences from Poland. Sustainability. DOI:10.3390/su10114289.

Mendez-Lazaro, P. A., Terrasa-Soler, J. J., Torres-Pena, C., Guzman-Gonzalez, P., Rodriguez, S., Aleman, M. \& Seguinot, T. (2014). Tourism and climate conditions in San Juan, Puerto Rico, 2000-2010. Ecology and Society, 19(2): 11. DOI:10.5751/ ES06380-190211

Montgomery, S. S. \& Robinson, M. D. (2010). Empirical Evidence of the Effects of Marriage on Male and Female Attendance at Sports and Arts. Social Science Quarterly, 91(1).

Muniz, C., Rodriguez, P. \& Suarez, M. J. (2014). Sports And Cultural Habits By Gender: An Application Using Count Data Models. Economic Modelling, 36, 288-297.

Mura, L., \& Kljucnikov, A. (2018). Small Businesses in Rural Tourism and Agrotourism: Study from Slovakia. Economics and Sociology, 11(3), 286-300. DOI:10.14254/2071-789X.2018/11-3/17

Oklobdzija, S. (2015). The Role Of Events In Tourism Development. Bizlnfo Journal, 6 (2), 83-97, DOI:10.5937/BIZINF015020830

Peter, S. \& Anandkumar, V. (2015). Travel motivation-based typology of tourists who visit a shopping festival: An empirical study on the Dubai shopping festival. Journal of Vacation Marketing, 1-12. DOI: 10.1177/1356766715607587.

Peterson, R. A., Hull, P. C. \& Kern, R. M. (2000). Age and Arts Participation in 1982-1997. Santa Ana, CA: Seven Locks Press. Pompurova, K. (2014). Profil navštevnikov organizovaných podujati v domacom cestovnom ruchu. Trendy v podnikani, 4(2), 54-62.

Tervo, K. (2008). The Operational and Regional Vulnerability of Winter Tourism to Climate Variability and Change: The Case of the Finnish Nature - Based Tourism Entrepreneurs. Scandinavian Journal of Hospitality and Tourism, 8(4), 317-332, DOI: 10.1080/15022250802553696.

Tkaczynski, A. (2014). Festival Performance (FESTPERF) Revisited: Service Quality and Special Events. In Advances in Hospitality and Leisure, 227-235. https://doi.org/10.1108/S1745-3542(2013)0000009015

Turkay, O., Korkutata, A., YIImaz, O. (2018). Does Animation Services Really Matter? Journal of Tourism and Services 9(16), DOI: 10.29036/jots.v9i16.40

Valek, N. S. (2018). The Relationship Between Community Sporting Event Participants And The Media. The case of Abu Dhabi, Journal of Sport \& Tourism, DOI:10.1080/14775085.2018.1466348

Yolal, M., Woo, E., Cetinel, F., \& Uysal, M. (2012). Comparative Research Of Motivations Across Different Festival Products. International Journal of Event and Festival Management, 3(1), 66-80. DOI 10.1108/17582951211210942

Yoon, Y., Lee, Y. \& Lee, C. (2010). Measuring Festival Quality And Value Affecting Visitors' Satisfaction And Loyalty Using A Structural Approach. International Journal of Hospitality Management, 29, 335-342.

Любомир Кмеко, D. Sc., Університетський коледж бізнесу у Празі (Чеська Республіка);

Іржі Мезуланік, D. Sс., Університет підприємництва та права (Чеська Республіка);

Олена Каскакова, Ph.D., Університет Матея Бела у Банська Бистриці (Словацька Республіка);

Мехмет Цивелек, Ph.D., Університет підприємництва та права (Чеська Республіка).

Фактори впливу на попит культурних івентів в туризмі: кейс Чеської Республіки

Основною метою дослідження $\epsilon$ аналіз фоакторів, які впливають на попит проведення туристичних культурних івентів в Чеській Республіці. У рамках статті авторами висунуто вісім гіпотез. Інфоормаційну базу дослідження було згенеровано на основі результатів опитування 1666 респондентів серед подорожуючих різними туристичними напрямами Чеської Республіки. Методологічною базою дослідження є економіко-математичні та статистичні методи, а саме: тест Фрідмана, знаковий критерій Вілкоксона, U-тест Манна-Вітні та коефріцієнт кореляції Спірмена. Емпіричні результати дослідження підтвердили висунуту гіпотезу про те, що населення Чеської Республіки вважають, що культурні івенти організовуються частіше, ніж спортивні та торгові заходи (наприклад, аукціони, виставки, ярмарки та релігійні заходи) в Чеській Республіці. У статті наголошено, що основними мотивами участі у культурних івентах серед суспільства сприйняття даних подій у якості розваг. Результати дослідження свідчать, що жінки частіше беруть участь у культурних івентах, ніж чоловіки. Встановлено, що чоловіки частіше відвідують спортивні змагання, ніж жінки. При цьому вищий рівень задоволення отримують від участі в 
L. Kmeco, J. Mezulanik, A. Kascakova \& M. Civelek. Factors of Demand for Cultural Events in Tourism: the Case of the Czech Republic

культурних івентах, аніж в інших заходах (спортивних заходах, виставках та ярмарках, релігійних заходах). Окрім цього, авторами спростовано гіпотезу, що літо - це найпривабливіший сезон для організації івентів. Визначено, що сімї частіше беруть участь у культурних івентах, ніж самотні особи чи особи з друзями. Авторами обгрунтовано та емпірично підтверджено, що реклама у засобах масової інформації має найбільший вплив на прийняття рішень щодо відвідування культурних івентів. На основі отриманих даних авторами систематизовано основні напрями активізації попиту на туристичні культурні заходи у Чеській Республіці. При иьому авторами виокремлено перспективні напрями подальших досліджень, а саме: вивчення специфіки організації та управління туристичними івентами, вплив якості організації туристичного івента на його популярність та кількість учасників.

Keywords: культурні заходи, виставки, ярмарки, тест Фрідмана, U-тест Манна-Вітні, коефіцієнт кореляції Спірмена, торгові події, спортивні змагання, знаковий критерій Вілкоксона.

Manuscript received: 19.08.2019.

(C) The author(s) 2019. This article is published with open access at Sumy State University. 